\title{
Monitoring P Efficiencies and Corn Yield by VAM and Sulfur Application in Calcareous Soils
}

\author{
Fatma K. Sherif, H.A. El-Attar, and Hoda A. Argeaa ${ }^{1}$
}

\begin{abstract}
Rare studies have been carried out on the use of Phytoavailability Soil Test (PST) using ion exchange resin capsules in calcareous soils. Resin capsules were used to monitor $P$ efficiencies due to Vascular Arbscular Mycorrhiza (VAM) inoculation and sulfur application in calcareous soil. Surface soil samples $(0-30 \mathrm{~cm})$ were collected from Nubaria region. Corn was used as a test plant. The obtained data showed that RAQ-P (Resin Adsorption Quantity) value increased with increasing soil $P$ supply. Generally, the highest concentration of available $-P$ was obtained after 60 days of adding $P$. Also it is clear that the RAQ-P value decreased at the third time (after 45 days) relative to the first time (15 days). RAQ was higher in mycorrhizal corn plants than the non-mycorrhizal. Also increasing $S$ levels significantly increased P-RAQ. The highest significant P-RAQ was recorded with the treatment of $100 \mathrm{~kg} \mathrm{P} \mathrm{Fed}^{-1}+O . M$ and $100 \mathrm{~kg} \mathrm{~S}$ inoculated.
\end{abstract}

\section{INTRODUCTION}

Calcareous soils are common in arid and semi-arid climates and occur as inclusions in more humid regions, affecting over 1.5 billion acres of soil worldwide and comprising more than $48000 \mathrm{Km}^{2}$ in the west part of Libya. Calcareous soil is poor in its fertility. Therefore, most crops grown on these soils suffer from $P$ stress and low fertility conditions.

Phosphorus $(\mathrm{P})$ is critical for plant growth and makes up about $0.2 \%$ of dry weight, but is one of the most difficult nutrients for plants to acquire. In soil, it may be present in relatively large amounts, but much is poorly available because of the very low solubility of phosphates of $\mathrm{Fe}, \mathrm{Al}$ and $\mathrm{Ca}$, leading to soil solution concentrations of $10 \mu \mathrm{M}$ or less and very low mobility (Schachtman et al., 1998). Accordingly, plants have evolved a range of strategies that either increase $\mathrm{Pi}$ uptake capacity or availability of Pi in soil (Marschner, 1995.). The most common of these strategies worldwide is arbuscular mycorrhizal (AM) symbiosis. AM increases phosphorus (P) acquisition, involving approximately $80 \%$ of terrestrial plants. The AM fungal symbionts provide a very effective pathway for uptake, scavenging from large soil volumes and overcoming depletion in the rhizosphere, (Smith, 2011).

Liu et al. (2000) evaluated the effect of $\mathrm{N}$ and $\mathrm{P}$ supply levels on mycorrhizal formation and nutrient uptake in corn hybrids. Mycoirhizal colonization of corn hybrids and the quantity of extraradical hyphae produced in soil were greatest at the lowest $\mathrm{P}$ level and at the intermediate $\mathrm{N}$ level. The shoot concentrations of $\mathrm{P}, \mathrm{Mg}, \mathrm{Zn}$ and $\mathrm{Cu}$ were significantly higher in mycorrhizal plants than in non-mycorrhizal plants. This trend was agreed with those obtained by (Smith and Read, 2008) who observed that growth differences between $\mathrm{AM}$ and $\mathrm{NM}$ plants tend to disappear as available soil $\mathrm{P}$ is increased. Ryan and Angus (2003) reported that total wheat $\mathrm{Zn}$-uptake and grain $\mathrm{Zn}$ concentration were positively correlated with colonization by AMF, due to enhanced $\mathrm{Zn}$-uptake after anthesis. For wheat, high colonization also corresponded with reduced Mn-uptake and lower grain Mn concentrations.

Sulphur application to calcareous soil plays an important role in soil such as reducing soil $\mathrm{pH}$, improving soil water relations, and increasing availability of nutrient elements. The residual effect of sulfur application was recently studied by Abdel Halim (2001) where $\mathrm{pH}$ decreased by 7.2, 7.0 and $1.2 \%$ for the three successive seasons, respectively. He attributed that to the long term oxidation of applied elemental sulfur into sulfates $\left(\mathrm{SO}_{4}\right)^{-2}$ and formation of sulfuric acid providing more $\mathrm{H}^{+}$ions in soil. Saleh (2001) found that application of elemental $\mathrm{S}$, to a highly calcareous soil (33.5\% CaC03) released significant amounts of Olsen-P from the soil. This work suggested that the availability of soil $\mathrm{P}$ is a $\mathrm{pH}$-dependent process and the application of the direct or indirect soil acidified amendments will greatly help in $\mathrm{P}$ solubilization in calcareous soils specially the carbonate-occluded P. At the same time the addition of sulfur has a great effect on increasing marjoram and broad bean yield due to its amendatory action on soil $\mathrm{pH}$ and consequently in increasing the availability of macro-nutrients .

The Universal Bioavailability Environment/Soil Test (UNIBEST) provides a good methodology for testing and monitoring soil. Skogley (1992) reported that there were many advantages for the resin methodology. 1- It is considered as Universal extraction where solutes both active and negative charged could be accumulated in a single capsule, 2- Bioavailability, where accumulation dynamic for each element are similar to those involved

\footnotetext{
${ }^{1}$ Soil and water science dept. College of Agriculture,

Alexandria University, Alexandria, Egypt

Received February18,2013, Accepted March 24, 2013
} 
in solute uptake by bioorganisms. 3- Environment/Soil Test to provide the basis for (environmental; testing/ monitoring) as well as (soil testing).

Sherif and Hedia (2001) used Amberlite IRN-150 resin capsule to determine its utility as a soil testing procedure in different Egyptian Soils using barley as test plant for 45 days. Strong correlation between Resin Adsorption Quantity values (RAQs) of NPK at S cm after 30 days and corresponding plant uptake obtained. Highly significant correlations between NPK availability using standard methods and the corresponding RAQs; $0.92,0.95$ and 0.91 were found, respectively. Hedia and Sherif (2004) determined phytoavailability soil test under salinity - induced changes in availability of $\mathrm{NH}_{4}-$ $\mathrm{N}, \mathrm{NO}_{3}-\mathrm{N}, \mathrm{P}, \mathrm{K}, \mathrm{Ca} / \mathrm{Mg}$ and $\mathrm{Na}$ in three different Egyptian soil types. (RAQs) of $\mathrm{Ca} / \mathrm{Mg}$ and $\mathrm{Na}$ increased with increasing ionic strength, while increasing SAR increased $\mathrm{Na}-\mathrm{RAQs}$ on the expense of $\mathrm{Ca} / \mathrm{Mg}-\mathrm{RAQs}$. Carlyle and Malcolm (1986) stated that ion exchange resins can remove ions from mass flow and receive ions by diffusion hence this approach can be considered diffusion sensitive. They added that it should be realized however that this will also reflect differences in initial solution concentration, nutrient release rates from solid phase, movement of ions towards the resin via gravitational solution transport, mass flow or other dynamics. Therefore, the objective of this study was to monitor $\mathrm{P}$ efficiencies due to VAM inoculation and sulfur application in calcareous soil by using resin capsules.

\section{MATERIALS AND METHODS}

\section{1- Soil}

Surface soil (top $30 \mathrm{~cm}$ ) was collected from Nubria region. The soil was air dried and sieved through 0.5 $\mathrm{mm}$ screen. Soil samples were analyzed for $\mathrm{pH}$ and E.C in the 1:1 soil: water extracts, for $\mathrm{P}$ by extraction with $\mathrm{NaHCO}_{3}$ and organic matter by rapid oxidation (Page et al., 1992), and soil texture analysis by the hydrometer method (Klute, 1990). The soil is basic and alkaline, poor in $\mathrm{N}$ and $\mathrm{P}$. Available $\mathrm{K}$ is considered to be adequate for normal plant growth. Some of the major soil characteristics are shown in Table 1.

\section{2- The pot experiment}

Greenhouse experiment was conducted under natural illumination. The treatments consisted of two factors: I) Five rates of $\mathrm{P}$ application $\left(0,100,200,250 \mathrm{~kg} \mathrm{P} \mathrm{Fed}^{1-}\right.$ , $100 \mathrm{~kg} \mathrm{P} \mathrm{Fed}^{-1}+10$ ton(O.M) as triple superphosphate and $\left(0,50,100 \mathrm{~kg} \mathrm{~S} \mathrm{Fed}^{-1}\right)$ and ii) two levels of AMF inoculation (inoculated and non inoculated). For the inoculated treatments, the soil was inoculated with a mixture of AMF. The mycorrhizal inoculums mixture consisted of $100 \mathrm{CC}$ of mixture of soil with the adhering spores and AMF-colonized chickpea root segments. The mixture contained $1 * 10^{5}$ at $1 \mathrm{ml}$. The inoculum's mixture was thoroughly mixed with the middle third of the soil in the pot. Before planting, the soil in each pot $(3 \mathrm{~kg}$ soil per pot) was watered with distilled water to field capacity and equilibrated.

Two pot trials were conducted throughout the summer and winter seasons (2010-2011) in the green house at Faculty of Agriculture, El-Shatby Alexandria University. Plastic pots $(25 \mathrm{~cm}$ diameter and $30 \mathrm{~cm}$ height) have three holes in their bottom for drainage purposes, were uniformly packed with $3 \mathrm{~kg}$ soil of $1.65 \mathrm{gm} \mathrm{cm}^{-3}$ bulk density.

\section{3- Plant}

Corn (Zea Maize L.) variety was seeded at a rate of 4 seeds per pot where after germination they were thinned to two homogeneous plants per pot. Corn seeds were sown at September 2010. All pots were amended with $125 \mathrm{mg} \mathrm{N} \mathrm{kg}^{-1}$ soil as ammonium sulfate. During the growing period each pot was periodically watered to maintain the soil moisture at approximate field capacity.

\section{4- Experimental Design}

A split split plot design with three replicates was carried out. Mineral phosphorus application representing main plot, was added at the rates of $0,100,200,250 \mathrm{Kg}$ fed $^{-1}$ and 10 ton (0.M) fed ${ }^{-1}$.

Sulphur application, representing the sub plot, were added at the rates of 0,50 and $100 \mathrm{Kg} \mathrm{Fed}^{-1}$.

The total trials were 30 with three replicates. Farm Yard Manure (FYM) used in this experiment as a source of phosphorus in the soil. The chemical analysis of (FYM) were analyzed according to (Page et al.,1992) and shown in Table (2).

The recommended doses for corn were $200 \mathrm{~kg}_{2} \mathrm{O}_{5}$ for phosphorus as Triple phosphate and potassium $50 \mathrm{~kg}$ $\mathrm{K}_{2} \mathrm{SO}_{4}$ (Potassium Sulphate), the nitrogen rates were added in two equal doses, the first addition was after three weeks from planting and the second was added after 45 days from planting.

After 30 and 60 days from planting, corn plants samples were collected and washed out of the soil to determine the physiological parameters of plant morphology as follows:

\section{1- Fresh weight (g plant ${ }^{-1}$ )}

The whole plant (root, and shoot) fresh weight was obtained at harvest time for two plants for every treatment; the average was calculated and recorded.

\section{2- Dry weight $\left(\right.$ g plant $\left.^{-1}\right)$}

Shoot and root samples were oven dried at $65^{\circ} \mathrm{c}$ for 24 hours until a constant weight, and then the average was calculated and recorded. 
Table 1. Some physical and chemical properties of soil

\begin{tabular}{lclc}
\multicolumn{1}{c}{ Soil Properties } & value & \multicolumn{1}{c}{ Soil Properties } & value \\
\hline Particular size distribution & & & \\
\hline Sand \% & 63.7 & $\mathrm{HCO}_{3}{ }^{-}\left(\mathrm{meql}^{-1}\right)$ & 2.6 \\
\hline Silt \% & 12.8 & $\mathrm{Cl}^{-}\left(\mathrm{meql}^{-1}\right)$ & 7.5 \\
\hline Clay \% & 23.5 & $\mathrm{Ca}^{+2}\left(\mathrm{meql}^{-1}\right)$ & 3.2 \\
\hline Soil texture & Sandy clay loam & $\mathrm{Mg}^{+2}\left(\mathrm{meql}^{-1}\right)$ & 2.5 \\
\hline Moisture content $\%$ & 2.51 & $\mathrm{~K}^{+}\left(\mathrm{meql}^{-1}\right)$ & 0.93 \\
\hline Hydraulic conductivity m d & & $\mathrm{Na}^{+}\left(\mathrm{meql}^{-1}\right)$ & 6.57 \\
\hline Bulk density & 0.097 & $\mathrm{SO}{ }^{-}\left(\mathrm{meql}^{-1}\right)$ & 3.1 \\
\hline $\mathrm{pH}(1: 1)$ & 1.65 & Available phosphorus $\left(\mathrm{mgkg}^{-1}\right)$ & 22.50 \\
\hline $\mathrm{EC}\left(\mathrm{dSm}^{-1}\right)(1: 1)$ & 8.03 & Total carbonate $(\%)$ & 18.69 \\
\hline $\mathrm{CO}_{3}{ }^{2}\left(\mathrm{meql}^{-1}\right)$ & 1.32 & Organic matter $(\%)$ & 2.26 \\
\hline
\end{tabular}

Table 2. The Chemical analysis of Farm Yard Manure (FYM)

\begin{tabular}{lclc}
\hline Properties & & Properties & \\
\hline $\mathrm{pH}(1: 1)$ & 8.20 & $\mathrm{~K}^{+}\left(\mathrm{meql}^{-1}\right)$ & 5 \\
\hline $\mathrm{EC}\left(\mathrm{dsm}^{-1}\right)(1: 1)$ & 7.00 & $\mathrm{Cl}^{-}\left(\mathrm{meql}^{-1}\right)$ & 40.7 \\
\hline $\mathrm{CO}_{3}^{2}\left(\mathrm{meql}^{-1}\right)$ & - & $\mathrm{SO}_{4}{ }^{-1}\left(\mathrm{meql}^{-1}\right)$ & 22.3 \\
\hline $\mathrm{HCO}_{3}\left(\mathrm{meql}^{-1}\right)$ & 7 & Phosphorus $\left(\mathrm{mgkg}^{-1}\right)$ & 50 \\
\hline $\mathrm{Ca}^{2+}\left(\mathrm{meql}^{-1}\right)$ & 25 & Total nitrogen $(\%)$ & 0.13 \\
\hline $\mathrm{Mg}^{2+}\left(\mathrm{meql}^{-1}\right)$ & 28 & $\mathrm{C} / \mathrm{N}$ ratio & 38.00 \\
\hline $\mathrm{Na}^{+}\left(\mathrm{meql}^{-1}\right)$ & 12 & Organic matter $(\%)$ & 8.50
\end{tabular}

\section{5-Plant and soil analysis}

Plant samples at 30 days and 60 days after planting were collected oven dried at $65 \mathrm{C}^{\circ}$ for 48 hours, ground then homogenized and $0.5 \mathrm{~g}$ oven dried plant material was wet digested with $\mathrm{H}_{2} \mathrm{SO}_{4}-\mathrm{H}_{2} \mathrm{O}_{2}$ (FAO, 1980) for chemical analysis. In the digested solution of plant or grain, phosphorus was determined using the vanadomolybdic acid method (Jackson, 1958).

After plant harvesting soil samples were taken from the pots, ground and subjected to some chemical analysis such as: EC - pH (Page et al., 1992) and available phosphorus (Olsen and Sommers, 1982).

\section{6-Statistical analysis:}

A split-split plot design with three replicates was used. Mycorrhiza with and without application occupied the sub -sub plots. The three sulfur rates were allocated to the sub-plots, while the five phosphorus rates were assigned to the main plots.

\section{7- Ion exchange resin accumulators}

Amberlite IRN-150 (Rohm and has CO; Philadelphia, PA) was used as the resin mixture. This nuclear-grade mixed-bed ion-exchange resin is a 1:1 equivalent mixture of strongly acidic cation $\left(\mathrm{H}^{+}\right)$and strongly basic anion $(\mathrm{OH})$ exchanges resin.

Five milliliters of wet Amberlite IRN-150 were packed into 140-um-opening polyester cloth and tied with braided polyester thread to form a tight sphere with a diameter of $2.5 \mathrm{~cm}$ and surface area of $19.64 \mathrm{~cm}^{2}$.

The cloth and thread were cleaned with dilute $\mathrm{HCl}$ prior to use. The resin accumulators were trimmed of excess cloth and thread repeatedly cleaned by flushing with double-distilled deionized water, and degassed under water in vacuum desiccators .This is a very important step in resin preparation because it removes air from the small resin pores and allows the solution to contact the exchange sites which would otherwise be blocked by air .The resin was then leached with $10 \%$ $\mathrm{HCl}$ for 48 hours to insure complete $\mathrm{H}$ - saturation of the resin .The accumulators were stored under water in a sealed glass container until used .Resin capsules (PST-1) were obtained from UNIBEST,INC.

At the second week the resin accumulators were inserted into the center of each pot hole, ensuring that they were in complete contact with the surrounding soil.

The resin accumulators were replaced every two weeks by new resins, and thoroughly washed with double-distilled water to remove all adhering soil particles.

Each accumulator was then placed in a small snapcap container and frozen until stripped of accumulated nutrients.

Each resin capsule was then placed in the top of 60$\mathrm{ml}$ plastic bottle, and $2 \mathrm{~N} \mathrm{HCl}$ was used to extract 
different ions from resin for $30 \mathrm{~min}$ drop-wise extraction

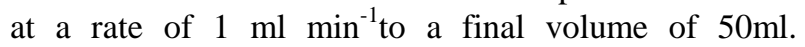
Solutions were analyzed for $\mathrm{P}$.

Total quantity of each nutrient recovered from the accumulators is referred to as resin adsorption quantity per unit surface area RAQ $\left(\mathrm{mmol} \mathrm{cm} \mathrm{cm}^{-2}\right)$.

\section{RESULTS AND DISCUSSIONS}

\section{1- Shoot fresh and dry weight}

Table (3) showed that increasing soil $\mathrm{P}$ supply reduced corn shoot fresh and dry weights of infected plants up to $100 \mathrm{~kg}$ superphosphate Fed $^{-1}$ compared with control. This trend was found with all sulfur treatment.

The same trend was observed by Kizilgoz and Sakim, (2010) who referred this decrease in shoot and dry weight to $\mathrm{Zn}$ deficiency due to $\mathrm{P}$ increasing.

By increasing soil $\mathrm{P}$ fertilizer than $100 \mathrm{~kg} \mathrm{Fed}^{-1}$, it is clearly noticed that corn shoot fresh and dry weights increased significantly in both infected and non infected plants compared to control.

In comparison between the mycorrhizal and nonmycorrhizal plants, it is clear from Table (3) that mycorrhiza infection increased fresh and dry weights significantly. The highest increase observed with control treatment at zero $\mathrm{S}$ rate that reach $111 \%$ for fresh weight. This may be due to the activity of mycorrhiza which increased with $\mathrm{P}$ decreasing, while the highest increase in dry weight was found with the fourth $\mathrm{P}$ treatment $\left(250 \mathrm{~kg} \mathrm{P} \quad \mathrm{Fed}^{-}\right)$that represented $52 \%$ compared with the non-infected plants.

It is clear also that the effect of mycorrhiza on the highest dry weight decreased with increasing sulfur application. The observed increasing were 52, 43 and $20 \%$ between mycorrhizal and non-mycorrhizal plants for the application rates 0,50 and $100 \mathrm{~kg} \mathrm{~S} \mathrm{Fed}^{-1}$, respectively.

Indeed, it is noticed that increasing sulfur supply increased significantly the fresh and dry weight of the infected plants compared with the non-infected plants. At the highest dose of $\mathrm{S}\left(100 \mathrm{~kg} \mathrm{~S} \mathrm{Fed}^{-1}\right)$, the fresh weight increased with increasing $\mathrm{P}$ application. This may be due to the acidification effect of $\mathrm{S}$ in calcareous soil.

Concerning, the interaction between mycorrhiza and sulfur it is noticed that the effect of this interaction was significant and the significance was higher in the fresh weight than the dry weight.

Also, the effect of interaction between mycorrhiza, $\mathrm{P}$, and sulfur recorded the same trend.

Table 3. Means of F.W \& D.W in corn shoot $\left(\mathrm{g} \mathrm{pot}^{-1}\right)$ after 30 days as influenced by the different treatments $P, S$ and Mycorrhiza and their combinations

\begin{tabular}{|c|c|c|c|c|c|c|c|c|c|}
\hline \multirow{7}{*}{ 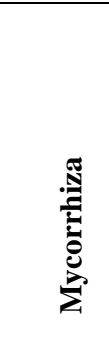 } & \multirow[t]{2}{*}{$\begin{array}{l}P \text { rates. } \\
\text { Kg/Fed }\end{array}$} & \multicolumn{4}{|c|}{$\begin{array}{c}\mathrm{F} . \mathrm{W}(\mathrm{gm}) \\
\text { S rates } \mathrm{Kg} / \mathrm{Fed} \\
\end{array}$} & \multicolumn{4}{|c|}{$\begin{array}{c}\mathrm{D} . \mathrm{W}(\mathrm{gm}) \\
\text { S rates Kg/Fed }\end{array}$} \\
\hline & & $\mathbf{0}$ & 50 & 100 & Mean & $\mathbf{0}$ & 50 & 100 & Mean \\
\hline & 0 & 4.60 & 4.90 & 4.90 & 4.85 & 0.50 & 0.51 & 0.50 & 0.50 \\
\hline & 100 & 3.30 & 2.90 & 6.40 & 4.41 & 0.30 & 0.22 & 0.60 & 0.37 \\
\hline & 200 & 5.10 & 5.10 & 6.70 & 5.67 & 0.80 & 0.50 & 0.55 & 0.62 \\
\hline & 250 & 6.60 & 6.70 & 5.90 & 6.48 & 0.60 & 0.69 & 0.60 & 0.67 \\
\hline & O.P & 6.60 & 4.90 & 6.50 & 6.04 & 0.60 & 0.52 & 0.70 & 0.63 \\
\hline Mean & & 5.30 & 4.90 & 6.10 & & 0.56 & 0.49 & 0.59 & \\
\hline \multirow{5}{*}{ 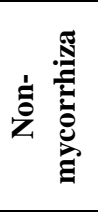 } & 0 & 2.70 & 1.40 & 2.70 & 2.29 & 0.30 & 0.17 & 0.30 & 0.30 \\
\hline & 100 & 2.40 & 2.30 & 2.10 & 2.27 & 0.29 & 0.51 & 0.20 & 0.33 \\
\hline & 200 & 4.40 & 2.70 & 2.10 & 3.07 & 0.80 & 0.34 & 0.20 & 0.48 \\
\hline & 250 & 5.60 & 3.90 & 4.90 & 4.80 & 0.30 & 0.48 & 0.50 & 0.44 \\
\hline & O.P & 5.00 & 4.80 & 5.80 & 5.20 & 0.80 & 0.47 & 0.80 & 0.73 \\
\hline Mean & & 4.02 & 3.02 & 3.52 & & 0.60 & 0.39 & 0.40 & \\
\hline \multicolumn{5}{|c|}{ LS.D ${ }_{0.05}$ mycorr. $=0.82$} & \multicolumn{5}{|c|}{ LS.D $_{0.05}$ mycorr. $=0.04$} \\
\hline \multicolumn{5}{|c|}{ LS.D ${ }_{0.05}$ mcorr. $*$ sulfur $=1.05$} & \multicolumn{5}{|c|}{ LS.D ${ }_{0.05}$ mcorr. $*$ sulfur $=0.10$} \\
\hline \multicolumn{5}{|c|}{ LS.D ${ }_{0.05}$ Sulfur*p=- } & \multicolumn{5}{|c|}{ LS.D ${ }_{0.05}$ Sulfur*p $=-$} \\
\hline \multicolumn{5}{|c|}{ LS.D ${ }_{0.05}$ Sulfur $=0.74$} & \multicolumn{5}{|c|}{ LS.D ${ }_{0.05}$ Sulfur $=0.07$} \\
\hline \multicolumn{5}{|c|}{ LS.D $D_{0.05} \mathrm{p}=1.02$} & \multicolumn{5}{|c|}{ LS. $D_{0.05} P=0.11$} \\
\hline \multicolumn{5}{|c|}{ LS.D ${ }_{0.05}$ mycorr* $\mathrm{p}=1.45$} & \multicolumn{5}{|c|}{ LS.D ${ }_{0.05}$ mycorr*p $=0.09$} \\
\hline \multicolumn{5}{|c|}{ LS.D ${ }_{0.05}$ mycorr*p*sulfur $=2.51$} & \multicolumn{5}{|c|}{ LS.D ${ }_{0.05}$ mycorr*p*sulfur $=0.28$} \\
\hline
\end{tabular}


In contrast to the data shown in Table (3), the data presented in Table (4) summarized the mean fresh and dry weights for the second harvest after 60 days. It is clear that increasing $\mathrm{P}$ supply reduced shoot fresh and dry weights compared to control treatment at zero rate of sulfur application, but this decrease was not significant.

Concerning, the effect of mycorrhiza the data in table (4) showed that mycorrhiza increased shoot fresh weight and dry weight significantly. This increase declined from $71 \%$ to $43 \%$ from control to the fifth treatment $\left(250 \mathrm{~kg}\right.$ super phosphate $\left.\mathrm{Fed}^{-1}\right)$, respectively.

From Table (4), it is clear also that increasing $\mathrm{S}$ application increased significantly fresh and dry weight at 60 days harvest. The highest rate of Sulfur application recorded the highest fresh weight and dry weight.

The same trend was observed for the mycorrhizal and non-mycorryhizal plants.

For the interaction between mycorrhiza, $\mathrm{P}$, and sulfur, the statistical analysis illustrated that its effect was significant at $5 \%$.

In contrast to the trend observed for the effect of mycorrhiza after 30 days, it was found that the effect of mycorrhiza after 60 days was decreased with time. The increasing percentage was calculated for the highest dose of $\mathrm{P}$ rate $\left(250 \mathrm{~kg}\right.$ super phosphate $\left.\mathrm{Fed}^{-1}\right)$ and it reached 50,43 and $20 \%$ at 30 days while decreased to 8 , 12 and $19 \%$ at 60 days. This may be due to the decreasing activity of mycorrhiza with time. These data were confirmed with those obtained by Pearson and Gianinazi, 1978 who stated that the maximum enzyme activity occurred at the beginning of infection and declined with the development of both plant and VAM infection.

Fortunately, this observation was detected with the absence of sulfur, while after 60 days the data showed that the increasing percentage increased to 8,12 and $19 \%$ at 0,50 and $100 \mathrm{~kg} \mathrm{~S}^{-1}$ activity due to sulfur application.

\section{2- Phosphorus concentration}

In contrast to shoot dry matter, increasing soil $\mathrm{P}$ supply increased shoot and root $\mathrm{P}$ concentration (significantly). Compared to the control treatment, shoot $\mathrm{P}$ concentration was increased by approximately 106, 100,160 and $153 \%$ in corn plants at $0,100,200,250$ and the organic treatment, respectively (Table 5).

Although Mycorrhiza infection increased shoot and root $\mathrm{P}$ concentration significantly, but the extent of reduction varied between shoot and root, compared between infected and non-infected plants. Shoot $\mathrm{P}$ concentration increased by 69,16 and $12 \%$, while root $P$ concentration increased by 27,89 and $27 \%$ at 0,50 and $100 \mathrm{~kg} \mathrm{~S} \mathrm{Fed}^{-1}$. In general root appeared to accumulate more $\mathrm{P}$ than shoot. These results are confirmed with those obtained by Kizilgoz and Sakin (2010).

Concerning the interaction between mycorrhiza and sulfur, the statistical analysis showed a positive effect on phosphorous concentration in shoot while $\mathrm{P}$ concentration in root was not significant.

The presented data in Table (5) showed that the soil $\mathrm{P}$ concentration was positively affected by both soil infection and increasing rate of $\mathrm{P}$ application to soil. This may be due to the benefit effect of mycorrhiza on solubilizing $\mathrm{P}$ in soil solution.

In contrast, increasing sulfur application rate did not affect soil $P$ concentration significantly, but the interaction between mycorrhiza and sulfur and mycorrhiza and phosphorous was positively significant.

Availability of $\mathrm{P}$ for plant utilization is not a function of its concentration in the soil, but rather on the rate of its release from the soil surface into the soil solution.

\section{3- RAQ-P in resin capsule}

$P$ is considered the most unavailable and inaccessible of all mineral nutrients (Holford, 1997). Extraction methods used in evaluating $\mathrm{P}$ status of soils include extraction with water, weak acids, bases, salts and anion exchange resin. In comparison among some conventional chemical extractants and resin capsules, Abdou (2006) concluded that the use of exchange resin capsule may be the best provided soil extractant.

Data presented in Figs (1, 2, and 3) illustrated that RAQ value increased with increasing $P$ supply. These results agreed with the results obtained by (Sherif and Hedia, 2001) who found that increasing phosphorus fertilizer application rates increased the P- RAQ at $5 \mathrm{~cm}$ depth in calcareous soil.

Data in fig 1, 2 and 3 also indicated that the availability of $\mathrm{P}$ was increased with time. The rate of increment reached 27.6, 88.1, 90.2\% after 15, 30, 45 and 60 days respectively. Such results were confirmed by Agbenin and Tissen (1995) who found that P adsorption occurs rapidly in the first period and followed by a slow adsorption processes.

Generally, the highest concentration of available-P was obtained after 60 days of adding P. Also it is clear that the RAQ-P value decreased at the third time(after 45 days) relative to the first time ( 15 days) this may be due to the competition between root uptake and the extraction of resin capsules. This data confirmed with data obtained by Sherif (1996). 
Table 4. Means of F.W \& D.W in corn shoot harvest after 60 days as influenced by the different treatments $\mathbf{P , S}$ and Mycorrhiza and their combinations

\begin{tabular}{|c|c|c|c|c|c|c|c|c|c|}
\hline & P Kg/Fed & & & $\begin{array}{l}\text { (gm) } \\
\text { g/Fed }\end{array}$ & & & & $\begin{array}{l}W(\mathrm{gm}) \\
\mathrm{g} / \mathrm{Fed}\end{array}$ & \\
\hline & & 0 & 50 & 100 & Mean & $\mathbf{0}$ & 50 & 100 & Mean \\
\hline & 0 & 13.37 & 14.44 & 13.95 & 13.92 & 2.51 & 2.71 & 2.59 & 2.60 \\
\hline 胥 & 100 & 13.02 & 15.39 & 14.79 & 14.40 & 2.46 & 2.79 & 2.69 & 2.65 \\
\hline $\bar{E}$ & 200 & 13.49 & 13.62 & 15.50 & 14.20 & 2.55 & 2.60 & 2.84 & 2.66 \\
\hline$\stackrel{0}{0}$ & 250 & 13.07 & 14.22 & 15.62 & 14.30 & 2.49 & 2.68 & 2.84 & 2.67 \\
\hline & O.P & 13.54 & 14.71 & 15.17 & 14.47 & 2.57 & 2.76 & 2.75 & 2.69 \\
\hline Mean & & 13.30 & 14.47 & 15.01 & & 2.51 & 2.71 & 2.74 & \\
\hline & 0 & 11.54 & 12.31 & 11.40 & 11.75 & 2.32 & 2.42 & 2.31 & 2.35 \\
\hline$\stackrel{\widetilde{N}}{\mathscr{N}}$ & 100 & 12.43 & 12.14 & 11.71 & 12.09 & 2.45 & 2.45 & 2.38 & 2.42 \\
\hline $\bar{E}$ & 200 & 11.64 & 12.49 & 13.37 & 12.50 & 2.36 & 2.48 & 2.59 & 2.47 \\
\hline$\dot{z}$ & 250 & 12.44 & 13.05 & 12.91 & 12.80 & 2.47 & 2.39 & 2.37 & 2.41 \\
\hline & O.P & 12.39 & 12.60 & 11.92 & 13.21 & 2.42 & 2.56 & 2.45 & 2.48 \\
\hline Mean & & 12.09 & 12.52 & 12.26 & & 2.40 & 2.46 & 2.42 & \\
\hline LS.D $D_{0.05}$ & yycorr. $=0.19$ & & & & LS.D $D_{0.05} \mathrm{~m}$ & $r .=0.09$ & & & \\
\hline LS.D & corr. ${ }^{*}$ sulfur $=0$ & & & & LS. $\mathrm{D}_{0.05} \mathrm{~m}$ & *sulfur $=$ & & & \\
\hline LS.D ${ }_{0.05}$ & ulfur*p=1.32 & & & & LS.D ${ }_{0.05} S$ & $* \mathrm{p}=-$ & & & \\
\hline LS.D 0.05 & ulfur $=0.13$ & & & & LS.D ${ }_{0.05} S$ & $=-$ & & & \\
\hline LS.D & & & & & LS.D ${ }_{0.05} \mathrm{P}$ & & & & \\
\hline LS.D ${ }_{0.05}$ & nycorr*p= - & & & & LS.D ${ }_{0.05} \mathrm{~m}$ & $r^{*} p=-$ & & & \\
\hline LS.D ${ }_{0.05}$ & nycorr*p*sulfur & $=1.86$ & & & LS.D $\mathrm{D}_{0.05} \mathrm{~m}$ & $r * p *$ sulft & $=1.42$ & & \\
\hline
\end{tabular}

Table 5. Means of $P$ concentration in corn shoot $\&$ root and soil after 60 days of planting as influenced by the different $P, S$ and Mycorrhiza treatments and their combinations

\begin{tabular}{|c|c|c|c|c|c|c|c|c|c|c|}
\hline \multirow{7}{*}{ 宽 } & \multirow{2}{*}{$\begin{array}{c}\mathrm{P.} \\
\mathrm{Kg} / \mathrm{Fd}\end{array}$} & \multicolumn{3}{|c|}{$\begin{array}{c}P \text { concentration in corn } \\
\text { shoot }\end{array}$} & \multicolumn{3}{|c|}{$\begin{array}{l}P \text { concentration in corn } \\
\text { root }\end{array}$} & \multicolumn{3}{|c|}{$\begin{array}{c}P \text { concentration in soil } \\
\mathrm{mg} / \mathrm{kg}^{-1}\end{array}$} \\
\hline & & 0 & 50 & 100 & 0 & 50 & 100 & 0 & 50 & 100 \\
\hline & 0 & 0.22 & 0.25 & 0.31 & 0.29 & 0.35 & 0.38 & 33.75 & 42.85 & 38.85 \\
\hline & 100 & 0.30 & 0.33 & 0.29 & 0.30 & 0.35 & 0.42 & 40.00 & 56.25 & 46.25 \\
\hline & 200 & 0.26 & 0.29 & 0.30 & 0.26 & 0.45 & 0.29 & 50.20 & 58.25 & 51.05 \\
\hline & 250 & 0.44 & 0.35 & 0.28 & 0.37 & 0.53 & 0.55 & 40.90 & 56.25 & 59.60 \\
\hline & O.P & 0.33 & 0.27 & 0.40 & 0.32 & 0.40 & 0.61 & 67.60 & 66.50 & 63.65 \\
\hline Mean & & 0.31 & 0.29 & 0.32 & 0.31 & 0.42 & 0.45 & 46.89 & 56.02 & 51.88 \\
\hline \multirow{5}{*}{ 艺 } & 0 & 0.16 & 0.20 & 0.24 & 0.18 & 0.20 & 0.22 & 24.50 & 22.30 & 20.45 \\
\hline & 100 & 0.30 & 0.28 & 0.29 & 0.25 & 0.27 & 0.33 & 19.45 & 19.00 & 27.15 \\
\hline & 200 & 0.25 & 0.27 & 0.29 & 0.25 & 0.36 & 0.28 & 25.60 & 24.20 & 26.35 \\
\hline & 250 & 0.26 & 0.30 & 0.25 & 0.29 & 0.28 & 0.43 & 29.35 & 22.70 & 32.90 \\
\hline & O.P & 0.29 & 0.25 & 0.32 & 0.28 & 0.33 & 0.42 & 47.60 & 45.40 & 46.75 \\
\hline Mean & & 0.25 & 0.26 & 0.28 & 0.25 & 0.29 & 0.34 & 29.30 & 26.72 & 30.72 \\
\hline \multirow{2}{*}{\multicolumn{4}{|c|}{$\begin{array}{l}\text { LS.D0.05mycorr. }=- \\
\text { LS.D0.05mcorr. } * \text { sulfur }=0.20\end{array}$}} & \multicolumn{3}{|c|}{ LS.D0.05mycorr. $=20.37$} & \multicolumn{4}{|c|}{ LS.D0.05mycorr. $=0.93$} \\
\hline & & & & \multicolumn{3}{|c|}{ LS.D0.05mcorr. $*$ sulfur $=4.18$} & \multicolumn{3}{|c|}{ LS.D0.05mcorr.*sulfur= - } & \\
\hline \multicolumn{4}{|c|}{ LS.D0.05Sulfur*p=0.75 } & \multicolumn{3}{|c|}{ LS.D0.05Sulfur*p=5.43 } & \multicolumn{3}{|c|}{ LS.D0.05Sulfur* $\mathrm{p}=0.71$} & \\
\hline \multicolumn{4}{|c|}{ LS.D0.05Sulfur=0.14 } & \multicolumn{3}{|c|}{ LS.D0.05Sulfur= - } & \multicolumn{3}{|c|}{ LS.D0.05Sulfur= - } & \\
\hline \multicolumn{4}{|c|}{ LS.D0.05 p = - } & \multicolumn{3}{|c|}{ LS.D0.05 p=3.13 } & \multicolumn{3}{|c|}{ LS.D0.05 P= 0.41} & \\
\hline \multicolumn{4}{|c|}{ LS.D0.05mycorr* ${ }^{*}=-$} & \multirow{2}{*}{\multicolumn{3}{|c|}{$\begin{array}{l}\text { LS.D0.05mycorr* } *=4.43 \\
\text { LS.D0.05mycorr*p*sulfur }=\text { - }\end{array}$}} & \multirow{2}{*}{\multicolumn{3}{|c|}{$\begin{array}{l}\text { LS.D0.05mycorr*p }=0.58 \\
\text { LS.D0.05mycorr*p*sulfur }=\text { - }\end{array}$}} & \\
\hline \multicolumn{4}{|c|}{ LS.D0.05mycorr*p*sulfur= - } & & & & & & & \\
\hline
\end{tabular}




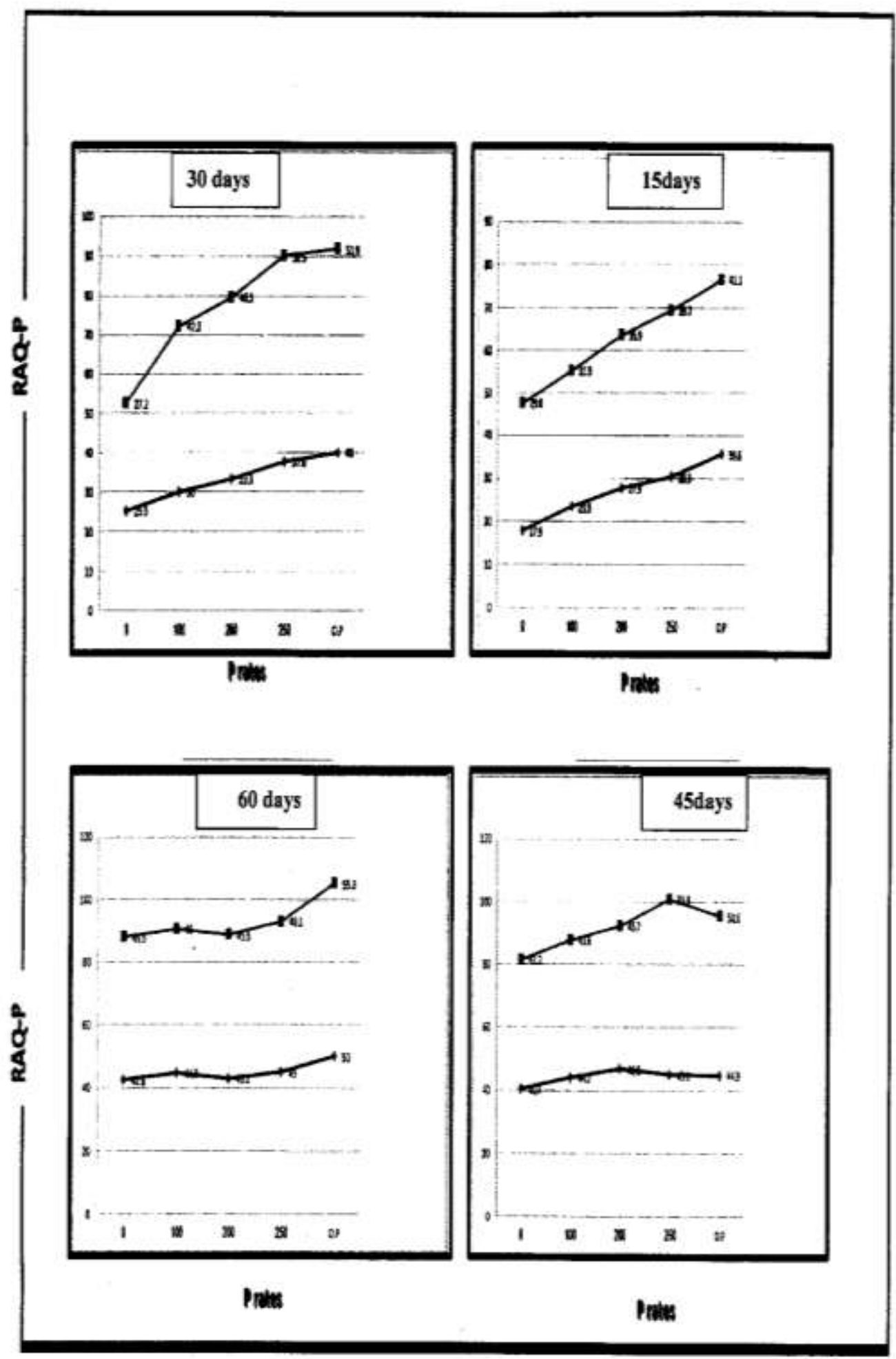

- mycorrhiza

- non-mycorrhiza

Fig. 1. $P$ concentration in resin capsules after 15, 30, 45 and 60 days in corn as affected by the different treatments of $P$, and mycorrhiza at zero $S$ kg application 


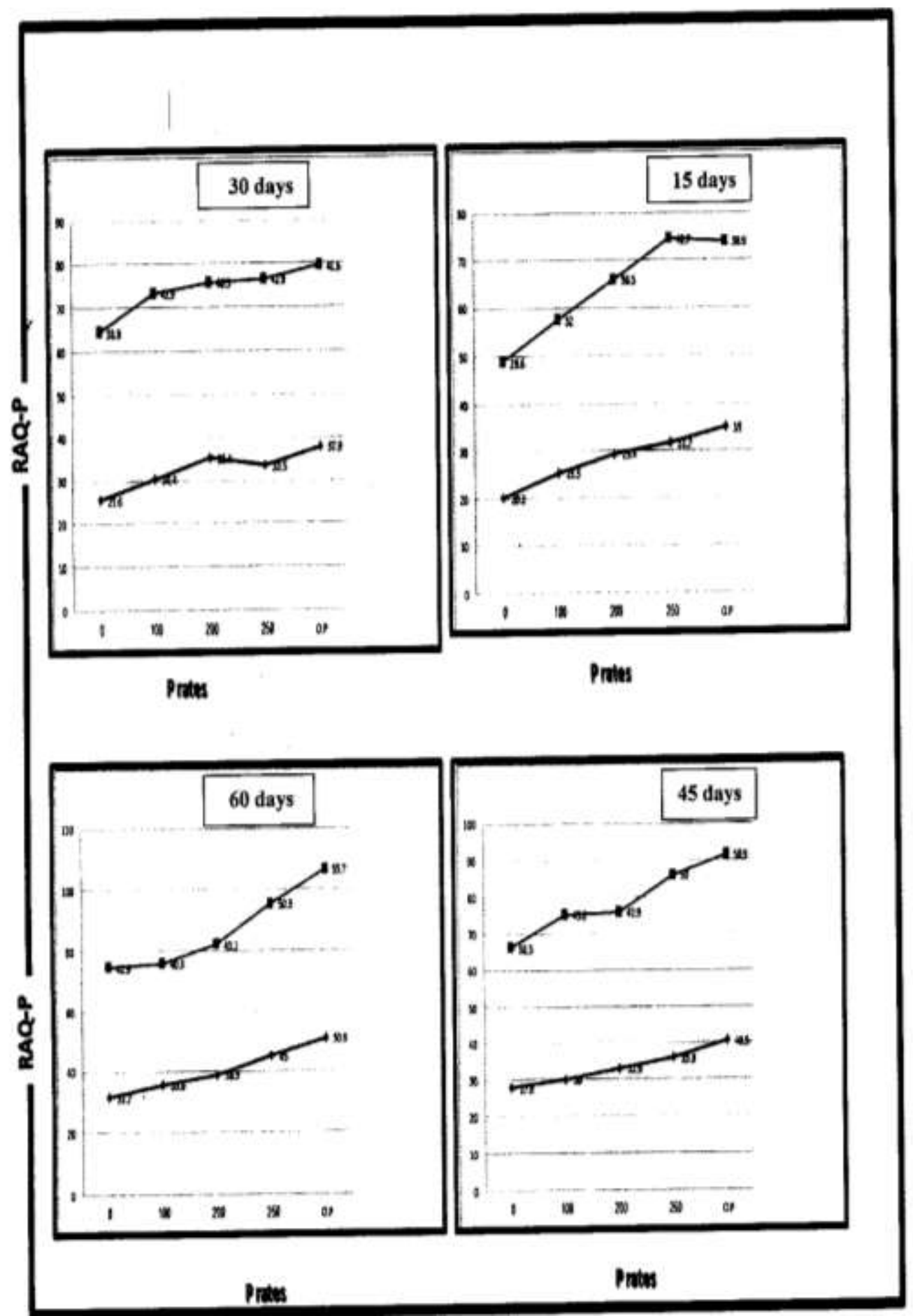

- mycorrhiza

- non-mycorrhiza

Fig. 2. $P$ concentration in resin capsules after 15, 30, 45 and 60 days in corn as effected by the different treatments of $P$, and mycorrhiza at $50 \mathrm{~kg} \mathrm{~S}$ 


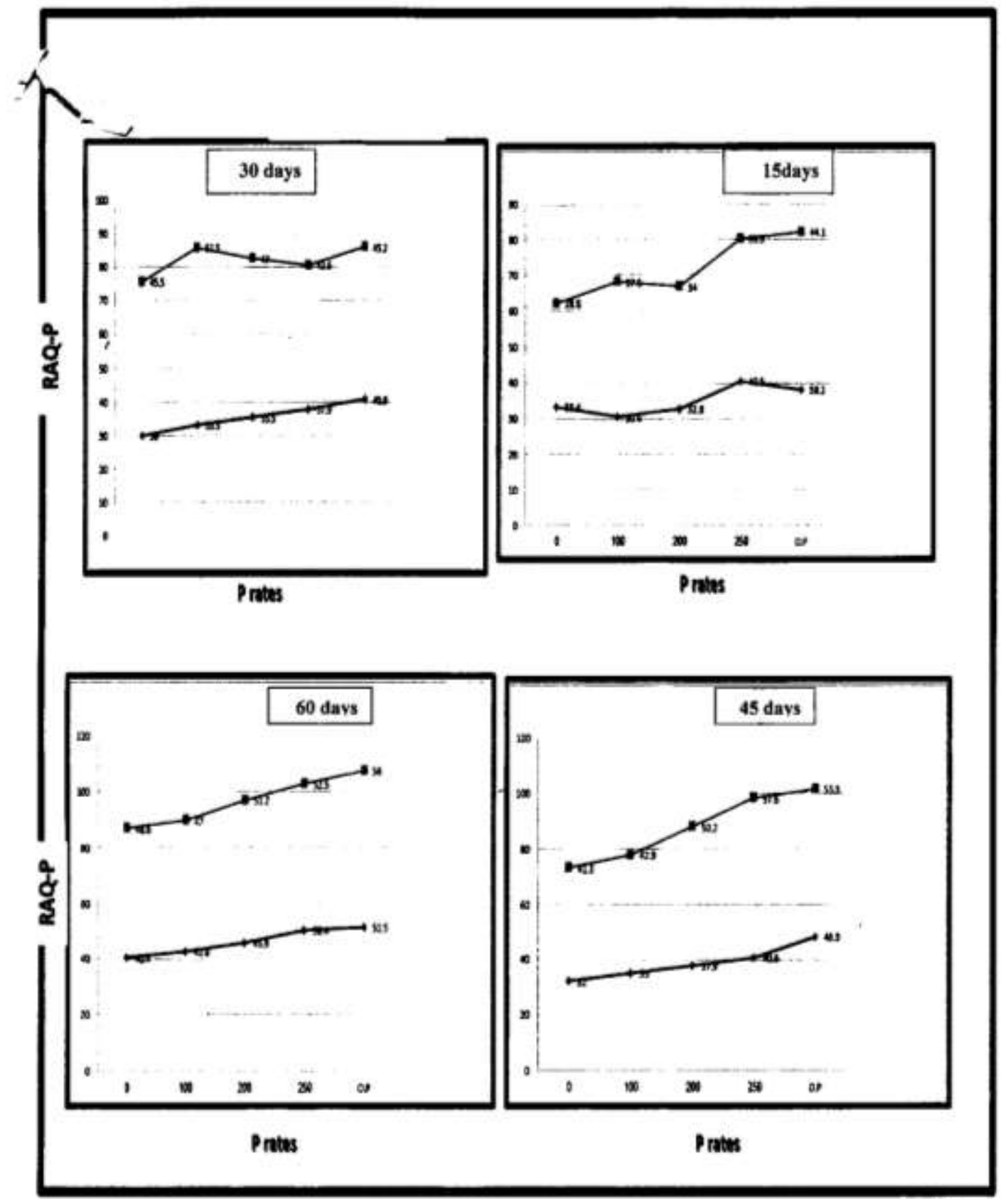

- mycorrhiza

- non-mycorrhiza

Fig. 3. $P$ concentration in resin capsules after 15, 30, 45 and 60 days in corn as effected by the different treatments of $P$, and Mycorrhiza at $100 \mathrm{~kg} S$ application

In comparison between the mycorrhizal and the nonmycorrhizal treatments, data presented illustrated that RAQ was higher in mycorrhizal treatment than the nonmycorrhizal that indicates the benefit effect of mycorrhizal in solubilizing P in soil and converted from unavailable into available form.
Concerning, the effect of $\mathrm{S}$ data showed that increasing sulfur rate increased RAQ value significantly in both infected and non-infected treatments. This increasing in $\mathrm{P}$-availability due to $\mathrm{S}$ application was obvious by the $\mathrm{S}$ role in decreasing soil $\mathrm{pH}$, which helped in transformation of insoluble $\mathrm{P}$ to available form 
Moreover, mixing the mineral fertilizer in the fifth treatment with organic manure caused a significant increase in available $\mathrm{P}$ relative to control. This is due to the beneficial effect of organic manure. It is needless to say that the applied organic manure, upon hydrolysis, may supply some organic function groups or anions such as citrate and oxalate that can effectively chelate $\mathrm{Ca}^{+2}$ ions and thus lower the $\mathrm{Ca}^{+2}$ activity in soil solution. This in turn provides a driving force for further availability of $P$. Direct evidence of chelating $\mathrm{Ca}^{+2}$ ions by the hydrolyzed soil organic matter was demonstrated by Savini et al., (2006). Indeed, the statistical analysis showed that the interaction among mycorrhiza, $\mathrm{P}$ and $\mathrm{S}$ increased the RAQ value significantly.

\section{REFERENCES}

Abdel-Halim, A.K. 2001. Effect of sulphur application on the main morophological, physical, chemical, and micromorphological properties of soils, and on production of some field crops. M.Sc. Thesis, Fac. Agric., Alex. Univ., Egypt.

Abdou, A.S. 2006. Effect of applied elemental sulfur and sulfur -oxidizing bacteria into calcareous sandy soils on the availability of native and applied phosphorus and some micronutrients.In:18thworld Congressof soil Science, Philadelphia, Pennsylvania , USA. July 9-15,2006.

Agbenin, J.O. and H. Tissen (1995). Phosphorus sorption at field capacity and soil ionic strength: Kinetics and transformation. Soil Sci. Soc. Am. J., 59:998-1005.

Carlyle, J.C. and D.C. Malcolm (1986). The use of ion exchange resins bags to assess $\mathrm{N}$ availability beneath pure spruce and larch + spruce on a deep peat soil. Plant \& Soil. 93:123-127.

FAO.1980.Soil and Plant analysis as basis of Fertilizer recommendations. Cottenie, A. Soils Bull., 38(2), Rome.

Hedia, R.M.R, and F.K. Sherif (2004).Reliability of phytoavailability soil test using resin capsules in some artificially - salinized Egyptian soils. Alex. J. Agric. Res. 49:107-117.

Holford I. C. R 1997. Soil phosphorus: its measurement, and its uptake by plants .Aust.J.Soil Res.35:227-239.

Kizilgoz I. and E Sakin. 2010.The effects of increased phosphorus application on shoot dry matter, Shoot $\mathrm{P}$ and Zn concentrations in Wheat (Triticun durum L.) and maize (Zea mays L.) grown in a calcareous Soil. African J. of Biotechnol. 9: 5893-5896.

Jackson, M.L.1958. Soil chemical Analysis prentice. Hall. Inc. Engle wood cliffs, N.J.,U. S.A.
Klute, A.(ed). 1990. Methods of soil Analysis. Physical and Mineralogical Methods. American Society of Agronomy Inc. Madison, Wisconsin.USA.

Liu A., C. Hamel, R.I. Hamilton, and D.L. Smith. 2000. Mycorrhizae formation and nutrient uptake of new corn (Zea mays L.) hybrids with extreme canopy and leaf architecture as influenced by soil $\mathrm{N}$ and $\mathrm{P}$ levels. Plant and Soil. 221 (2): 157-166.

Marschner H. 1995. Mineral Nutrition of Higher Plants. Academic Press, San Diego, CA.

Olsen S.R, L.E. Sommers. 1982. Phosphorous. In: A.L. Page, R.H. Miller, and D.R. Keeney. (ed). Methods of Soil Analysis. Agronomy. 9: 403-430.

Page A.L., R.H. Miller, and D.R Keency 1992. Chemical and Microbiological Properties. Madison, Wisconsin. U.S.A.

Pearson,G., and S. Gianinazzi. 1978. Enzymatic studies on the metabolism of vesicular-arbuscular mycorrhiza. II. Soluble alkaline phosphatase specific to mycorrhizal infection in onion roots. Physiol. PI. Pathol. 12: 45-53.

Ryan M.H., and J.F. Angus. 2003. Arbuscular mycorrhizae in wheat and field pea corps on a low P soil: increased Znuptake but no increase in P-uptake or yield. Plant \& Soil. 250 (2): 225-239.

Saleh, M.E. 2001. Some Agricultural applications for Biologically-Produced Sulfur Recovered from Sour Gases: 1- Effect on Soil Nutrient Availability in Highly Calcareous soils. Abu Dhabi, UAE, 24-25 February, 2001.

Savini, I.; Smithson, P.; and Karanja, N. 2006. Effect of added biomass, soil $\mathrm{pH}$, and Calcium on the solubility of phosphate rock in akenyan oxisol. Archives of Agron. S. S. 52:19-36.

-Schachtman,D.P., Reid, R.J., and Ayling, S.M. 1998. Phosphorus Uptake by Plants: From Soil to Cell. Plant Physiol. 116:447-453.

Sherif, F.K and R.M.R. Hedia (2001).Evaluation of resin capsule for monitoring availability and movement of nutrients in Egyptian soils. Alex. J. Agric. Res. 46:119128.

Sherif, F.K. 1996. Phytoavailability of zinc and copper by soybean and wheat growing in sand culture and sewage sludge amended soil in relation to plant growth and metal mobility in soil. Ph.D. Thesis Faculty of Agriculture, University of Alexandria. Alexandria. Egypt.

Skogley, E. 1992.The universal bioavailability environment /soil test unibest. Commun .Soil Sci. Plant Anal., 23(1720), 2225-2246.

Smith, S. E. 2011. Arbuscular mycorrhizas and phosphorus nutrition. Plant Physiology Preview.5: 1104-1110.

Smith, S.E., and D.J. Read. 2008. Mycorrhizal Symbiosis, Ed 3. Academic Press, New York. 


\section{الملخص العربي}

\section{رصد كفاءة الفوسفور وإنتاجية الذرة من خلال إضافة الميكوريزا والكبريت في التربة الجيرية}

فاطمة شريف، حاتم العطار، وهدى أرجيعة

$$
\begin{aligned}
& \text { وبوجة عام، تم الحصول على أعلى نسبة من P- بعد } 60 \text { يوما من } \\
& \text { لقـــ أجريست دراسـات قليلـة على اسـتخدام اختبــار التربـة } \\
& \text { phytoavailability (PST) }
\end{aligned}
$$

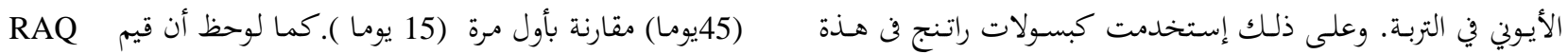

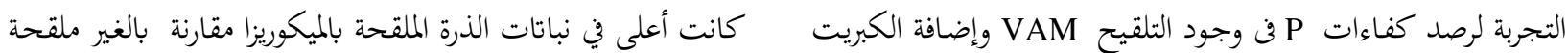

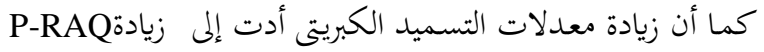

$$
\begin{aligned}
& \text { معنويا. } \\
& \text { وقد سجلت المعاملة (S } 100 \mathrm{Kg}+\mathrm{OM}+100 \mathrm{KgP} \text { ) } \\
& \text { الملقحة بالميكوريزا أعلى قيمجست المعامه (P-RAQ. }
\end{aligned}
$$

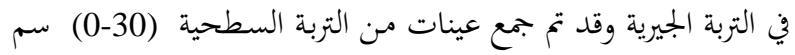

$$
\begin{aligned}
& \text { من منطقة النوبارية كما تم استخدام نبات الذرة في هذة التجربة. وقد }
\end{aligned}
$$

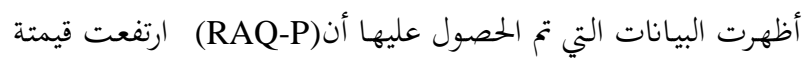

$$
\begin{aligned}
& \text { مع زيادة الفوسفور المضاف إلى التربة }
\end{aligned}
$$

